\title{
A new monopartite begomovirus species, Chilli leaf curl Vellanad virus, and associated betasatellites infecting chilli in the Vellanad region of Kerala, India
}

R. Vinoth Kumar, A.K. Singh and S. Chakraborty

Molecular Virology Laboratory, School of Life Sciences, Jawaharlal Nehru University, New Delhi -110 0676, India

*E-mail: supriyachakrasls@yahoo.com

Received: 19 Jan 2012. Published: 05 Apr 2012. Keywords: Capsicum annuum, leaf curling, sequence identity

Capsicum annuum (chilli) is one of the most important commercial crops cultivated in the Indian sub-continent for vegetable, spice and industria purposes. Leaf curl disease of chilli has become a serious problem in the Vellanad district of Kerala, one of the major chilli growing areas of India. Disease incidence up to 100\% was recorded during December 2008 in this region. The infected plants exhibited typical upward leaf curling, crinkling, puckering and reduction of leaf area along with stunting of whole plants (Fig. 1).

Total DNA was isolated from chilli plants and applied as template for PCR amplification of begomovirus-specific fragments using degenerate primer pairs (PAL1v1978/PAR1c496) for detection of Begomovirus DNA-A (Rojas et al., 1993) and Beta01/Beta02 for DNA- (Briddon et al., 2002). Specific fragments of $1.5 \mathrm{~kb}$ for DNA-A and $1.4 \mathrm{~kb}$ for DNA-, respectively, were obtained from samples associated with symptoms. Rolling circle amplification (RCA) using $\varphi 29$ DNA polymerase was carried out on the total DNA preparation, followed by digestion with Kpn I. An amplicon of $\sim 2.8 \mathrm{~kb}$ was gel-eluted and cloned into Kpn I-linearized pBluescript II KS(+). Restriction digestion of plasmid DNA from the resulting clones indicated the presence of one type of molecule. Betasatellite-specific amplicons of $\sim 1.4 \mathrm{~kb}$ were cloned into $\mathrm{pTZ} 7 \mathrm{R} / \mathrm{T}$. The corresponding satellite (sat) DNAs could be categorised into two groups based on their restriction pattern. In spite of repeated attempts, we failed to isolate DNA-B from the plants showing appropriate symptoms, indicating that the isolate was a monopartite begomovirus.

Full-length sequencing revealed a viral genome (HM007121) of 2,788 nt with seven predicted ORFs (AV1, AV2, AC1, AC2, AC3, AC4, AC5), Sequence alignment using MegAlign (DNASTAR, Madison, WI) showed the virus to have the highest levels of nucleotide sequence identity $(77 \%)$ with a 'Pakistan" strain of Pepper leaf curl Bangladesh virus (AF314531). With other chilli-infecting begomoviruses in the Indian sub-continent, there was between 64 and $76 \%$ sequence identity. The present virus is distinctly placed in a separate clade in the phylogenetic tree (Fig. 2). According to the ICTV guidelines (Fauquet et al., 2008), it has to be considered a new begomovirus species for which the name Chilli leaf curl Vellanad virus (ChiLCVeV) is proposed. The associated betasatellites (GenBank Accession Nos. JN663876, 1355 nt and JN663877, 1372 nt) each contain a single ORF $\mathrm{C} 1$. They share maximum identity of $95.6 \%$ and 96.9\% with Radish leaf curl betasatellite (EF175734) and Tomato leaf curl Bangladesh betasatellite (AY438558), respectively. Following ICTV guidelines (Briddon et al., 2008) along with phylogenetic analysis (Fig. 3) and nucleotide sequence identity data, the two molecules are therefore identified as isolates of satDNAs described earlier. Old World begomoviruses have been shown to be widely associated with one or more
DNA betasatellites (Briddon et al., 2003; Chattopadhyay et al., 2008). Together, these findings indicate that a new begomovirus species, ChiLCVeV,along with two distinct betasatellites (Radish leaf curl betasatellite and Tomato leaf curl Bangladesh betasatellite) are associated with chilli leaf curl disease in Vellanad, Kerala.

\section{Acknowledgements}

The authors gratefully acknowledge the Department of Biotechnology, India, for funding the research.

\section{References}

Briddon RW, Brown JK, Moriones E, Stanley J, Zerbini M, Zhou X, Fauquet CM, 2008. Recommendations for the classification and nomenclature of the DNA- $\beta$ satellites of begomoviruses. Archives of Virology 153, 763-781. [doi:10.1007/s00705-007-0013-6]

Briddon RW, Bull SE, Amin I, Idris AM, Mansoor S, Bedford ID, Dhawan P, Rishi N, Siwatch SS, Abdei-Salam AM, Brown JK, Zafar Y, Markham PG, 2003. Diversity of DNA $\beta$; a satellite moleculeassociatedwith some monopartite begomoviruses. Virology 312, 106-121. [doi:10.1016/j.physletb.2003.10.071]

Briddon RW, Bull SE, Mansoor S, Amin I, Markham PG, 2002. Universal primers for the PCR-mediated amplification of DNA $\beta$ : a molecule associated with some monopartite begomoviruses. Molecular Biotechnology 20, 315-318. [doi:10.1385/MB:20:3:315]

Chattopadhyay B, Singh AK, Yadav T, Fauquet CM, Sarin NB, Chakraborty S, 2008. Infectivity of the cloned components of a begomovirus: DNA- $\beta$ complex causing chilli leaf curl disease in India. Archives of Virology 153, 533-539. [doi:10.1007/s00705-007-0017-2]

Fauquet CM, Briddon RW, Brown JK, Moriones E, Stanley J, Zerbini M, Zhou X, 2008. Geminivirus strain demarcation and nomenclature. Archives of Virology 153, 783-821.

[doi:10.1007/s00705-008-0037-6]

Rojas MR, Gilbertson RL, Russel DR, Maxwell DP, 1993. Use of degenerate primers in the polymerase chain reaction to detect whitefly transmitted geminiviruses. Plant Disease 77, 340-347. [doi:10.1094/PD-77-0340]

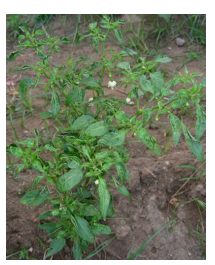

Figure 1

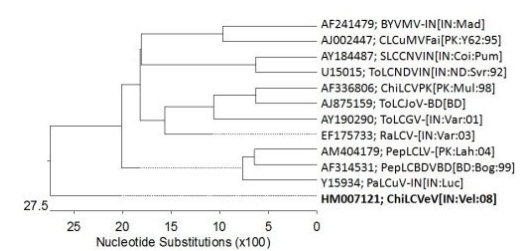

Figure 2

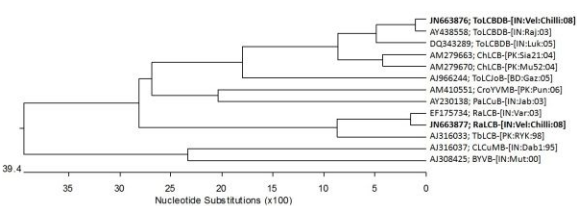

Figure 3

To cite this report: Vinoth Kumar R, Singh AK, Chakraborty S, 2012. A new monopartite begomovirus species, Chilli leaf curl Vellanad virus, and associated betasatellites infecting chilli in the Vellanad region of Kerala, India. New Disease Reports 25, 20. [doi:10.5197/j.2044-0588.2012.025.020] (c) 2012 The Authors 